Boston University School of Law

Scholarly Commons at Boston University School of Law

Faculty Scholarship

$12-2015$

\title{
The Intersection of Civil and Religious Family Law in the U.S. Constitutional Order: A Mild Legal Pluralism
}

Linda C. McClain

Boston University School of Law

Follow this and additional works at: https://scholarship.law.bu.edu/faculty_scholarship

Part of the Family Law Commons

\section{Recommended Citation}

Linda C. McClain, The Intersection of Civil and Religious Family Law in the U.S. Constitutional Order: A Mild Legal Pluralism, Religion, Secularism, and Constitutional Democracy 379 (2015).

Available at: https://scholarship.law.bu.edu/faculty_scholarship/226

This Book Chapter is brought to you for free and open access by Scholarly Commons at Boston University School of Law. It has been accepted for inclusion in Faculty Scholarship by an authorized administrator of Scholarly Commons at Boston University School of Law. For more information, please contact lawlessa@bu.edu. 


\title{
BU School of Law
}

\section{THE INTERSECTION OF CIVIL AND RELIGIOUS FAMILY LAW IN THE U.S. CONSTITUTIONAL ORDER: A Mild Legal Pluralism}

\author{
Boston University School of Law \\ Public Law \& Legal Theory Paper No. 17-13 \\ Religion, Secularism \& Constitutional Democracy (Jean L Cohen \\ and Cécile Laborde, Columbia University Press 2016), pp. 379- \\ 399.

\section{Linda C. McClain} \\ Boston University School of Law
}

This paper can be downloaded without charge at:

http://www.bu.edu/law/faculty-scholarship/working-paper-series/ 


\section{Religion,}

Secularism, \&

Constitutional

Democracy

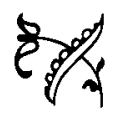

Edited by Jean L. Cohen

\& Cécile Laborde 


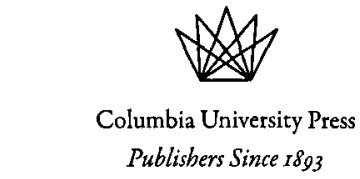

New York Chichester, West Sussex cup.columbia.edu

Copyright ${ }^{2} 2016$ Columbia University Press

All rights reserved

Library of Congress Cataloging-in-Publication Data

Religion, secularism, and constitutional democracy /

edited by Jean L. Cohen and Cecile Laborde.

pages $\mathrm{cm}$

Includes bibliographical references and index.

ISBN 978-0-231-16870-o (cloth : alk. paper) — ISBN 978-0-231-16871-7

(pbk. : alk. paper) - ISBN 978-0-231-54073-s (e-book)

I. Freedom of religion. 2. Religion and politics. 3. Religion and state.

4. Political theology. I. Cohen, Jean L., 1946-editor.

$$
\begin{gathered}
\text { BL640.R }{ }_{34} 2016 \\
322 \cdot 1-d c 23
\end{gathered}
$$

()

Columbia University Press books are printed on permanent and durable acid-free paper.

This book is printed on paper with recycled content.

Printed in the United States of America

cro98765432I

\section{Cover design: Jordan Wannemacher}

References to websites (URLs) were accurare ar the time of writing. Neither the author nor Columbia University Press is resporisible for URLs that may have expired or changed since the manuscript was prepared. 


\section{8) \\ Contents}

Introduction $I$

JEAN L. COHEN

\section{Part I: Freedom of Religion or Human Rights}

I. Religious Freedom.and the Fate of Secularism

27

SAMỦEĹL MOYN

2. Religion: Ally, Threat, or Just Religion?

ANNE PHILLIPS

3. Regulating Religion Beyond Borderś: The Case of FGM/C 66 YASMINE ERGAS

4. Pluralism vs. Pluralism: Islam and Christianity in the European Court of Humani Rights 89

CHRISTIAN JOPPKE

\section{Part II: Nonestablishments and Freedom of Religion}

5. Rethinking Political Secularism and the American Model of Constitutional Dualism II3

JEAN L. COHEN

6. Is European Secularism Secular Enough? $\quad$ I57

RAJEEV BHARGAVA

7. State-Religion Connections and Multicultural Citizenship $\quad{ }_{182}$ 
8. Breaching the Wall of Separation 204 DENIS LACORNE

9. Transnational Nonestablishment (Redux) 222 CLAUDIA E. HAUPT

\section{Part III: Religion, Liberalism, and Democracy}

Io. Liberal Neutrality, Religion, and the Good 249 CÉCILE LABORDE

II. Religious Arguments and Public Justification 273

AURÉLIA BARDON

12. Religious Truth and Democratic Freedom:

A Critique of the Religious Discourse of Anti-Relativism 293 CARLO INVERNIZZI ACCETTI

13. Republicanism and Freedom of Religion in France 316 MICHEL TROPER

\section{Part IV: Sovereignty and Legal Pluralism in Constitutional Democracies}

I4. Sovereignty and Religious Norms in the Secular Constitutional State $34 \mathrm{I}$ DIETER GRIMM

I5. Religion and Minority Legal Orders 358

MALEIHA MALIK

I6. The Intersection of Civil and Religious Family Law in the U.S.

Constitutional Ordẹr: A Mild Legal Pluralism 379

LINDA C. MCCLAIN

17. Religion-Based Legal Pluralism and Human Rights in Europe 400 ALICIA CEBADA ROMERO

Conclusion: Is Religion Special? 423

CÉCILE LABORDE

Contributors 435

Index 439 


\title{
16
}

\section{The Intersection of Civil and Religious Family Law in the U.S. Constitutional Order}

\author{
A Mild Legal Pluralism \\ LINDAC. MCCLAIN
}

T

This chapter considers how civil and religious family law intersect in the U.S. legal system and how U.S. constitutional law shapes and constrains there too little or too much pluralism in U.S. family law? In keeping with the First Amendment's prohibition on governmental establishment of religion, the United States has neither a robust or "strong" legal pluralism, which would treat state and non-state (religious) entities as authorities sharing coequal jurisdiction and power, nor a "state-law pluralism," which would delegate family-law matters to religious courts. ${ }^{2}$ Instead, U.S. courts often use the technique Maleiha Malik describes as "severance," in which they "consider issues on a case-by-case basis and distinguish between those of the minority legal order's norms that can be accommodated. without compromising liberal constitutional principles from those that must be rejected or prohibited."

Family law in the United States, I will argue, embraces a mild legal pluralism while clearly distinguishing between civil and religious marriage. As an entry point, I discuss the ongoing debate over whether civil family law should permit same-sex couples to marry. I then consider two categories of cases: ( 1 ) cases in which courts consider whether to enforce terms of religious marriage contracts, divorce agreements, or arbitration agreements, and (2) cases in which courts decide whether the principle of comity requires them to recognize foreign marriages and judgments of divorce. These cases highlight that U.S. family law generally accommodates 
religious pluralism, subject to constitutiònal norms and public policy. This chapter then argues that the recent enactment of state bans on the application of foreign law (so-called anti-sharia laws) reflects a misunderstanding-if not rejection-of this mild legal pluralism. These laws reflect an evident concern that there is a fundamental clash between the U.S. Constitution and sharia, and that, without such bans, courts will be on a slippery slope toward establishing a theocratic code that would replace the U.S. Constitution. ${ }^{4}$ Concerns over the equality of women in matters of family law feature calls for such bans. That concern is acute with respect to a third category of cases involving religion and the law: attempts to assert religious beliefs about family roles as a defense against public laws prohibiting domestic violence and sexual assault. Such appeals to religion or culture will not trump the protective policies of civil and criminal law. Through all of these examples, this chapter argues that legal pluralism in U.S. family law is appropriately mild rather than robust because such pluralism is within the frame of U.S. constitutional law and the commitments of family law.

\section{WHAT IS LEGAL PLURALISM?}

A broad understanding of legal pluralism would include the multiple sources of normative ordering in a society, not simply the "official" legal system found in cases, statutes, constitutions, administrative regulations, and the like, but also "unofficial" sources of law, such as religious regulation of marriage and divorce, rules, and customs.' Unofficial family law may have a formative effect on persons, families, and communities, even if it lacks the imprimatur of binding civil or state authoriry. ${ }^{6}$ The definition of legal pluralism that I use in this chapter distinguishes this normative pluralism - that people recognize and adhere to many sources of norms "other than those of the state's laws" - - from a narrower focus on that imprimatur of civil and state authority, given that "state law" is "fundamentally different" than non-state forms of ordering because "it exercises the coercive power of the state and monopolizes the symbolic power associated with state authority. ${ }^{8}$ Family law in the United States embraces a mild form of legal pluralism when U.S. courts "give official, or civil effect to certain aspects of religious family law." Such pluralism is appropriately constrained not only by "our fundamental 'political and constitutional values," such as equality, nondiscrimination, due process, and religious freedom, but also by "the protective policies that form the foundation for our particular rules of [U.S.] family law." ${ }^{\circ}$ 


\section{SHARED CIVIL AND RELIGIOUS AUTHORITY}

TO PERFORM MARRIAGES

A curious feature of U.S. family law is that although the constitution prohibits the establishment of religion, often interpreted as requiring the separation of church (and for that matter, synagogue and mošque) and state, civil and religious authorities cöoperate with respect to entry into marriage. Although state laws do not require a religious ceremony to validate a civil marriage, ${ }^{\text {,I }}$ such laws allow religious officiants to solemnize a marriage that is valid as a civil marriage, provided the formal requirements such as licensing are met. Thus, one ceremony may have dual effect: a couple is married in the eyes of their religious community and of the state.

If a couple fails to obtain a proper marriage license or if the religious officiant is not authorized under civil law to perform the ceremony, that marriage may be valid for purposes of religious law but invalid civilly. Nonetheless, reflecting family law's strong public policy favoring marriage, state family law often provides curative doctrines allowing marriages with procedural defects to be found valid. ${ }^{12}$ However, if a couple has a religious marriage not recognized under civil law, they lack the protections of civil family law, such as duties of economic support during marriage and entitlements to property distribution and spousal support at divorce. ${ }^{13}$

That U.S. family law permits solemnization of marriage in a religious ceremony to create a valid civil marriage suggests a mild form of legal pluralism. By incorporating "unofficial law and norms into the civil rite, the state appropriates and reinforces the solemnity of the occasion for its own purposes," such as impressing "the couples and the community with the seriousness of the marriage commitment." ${ }^{14}$

\section{DISTINGUISHING CIVIL AND RELIGIOUS MARRIAGE:}

\section{THE EXAMPLE OF SAME-SEX MARRIAGE}

That religious officials may perform marriages with civil effects reflects U.S. family law's roots in early English marriage law, when marriage "was the exclusive concern of ecclesiastical courts and the canon law."' Civil family law bears the traces of these ecclesiastical origins, but "in America marriage has always been regulated by the civil law," with "many state statutes" explicitly "providing that matriage is a civil contract. ${ }^{16}$ The state, in effect, is a third party to every marriage contract.

The ongoing battle over access by same-sex couples to civil marriage reveals the significance of the distinction between civil and religious marriage. As the Massachusetts Supreme Judicial Court stated in Goodridge v. Department of Public 
Health, in which it ruled that the Massachusetts state constitution required that same-sex couples be allowed to marry: "Simply put, the government creates civil marriage. In Massachusetts, civil marriage is, and since pre-colonial days has been, precisely what its name implies: a wholly secular institution." ${ }^{17}$ As the court explained, although people-and religious denominations-differ in their moral and religious views about the morality of homosexuality and the definition of marriage, that is irrelevant to the legal and constitutional question of whether same-sex couples may be denied access to civil marriage. ${ }^{18}$ As state legislatures revise state laws to allow same-sex couples to marry, lawmakers similarly stress marriage as a civil institution, crafting laws with a two-pronged focus on promoting marriage equality and protecting religious freedom through religious exemptions so that religious clergy, religious institutions, and benevolent organizations need not provide facilities or goods and services related to solemnizing or celebrating such marriages in violation of their religious beliefs.19

By contrast, when Congress passed the Defense of Marriage Act (DOMA) in 1996, the U.S. House of Representatives report explicitly intertwined civil and religious marriage in explaining DOMA's purposes: "Civil laws that permit only heterosexual marriage reflect and honor a collective moral judgment about human sexuality. This judgment entails both moral disapproval of homosexuality, and a moral conviction that heterosexuality better comports with traditional (especially Judeo-Christian) morality." ${ }^{\prime 0}$ This rhetoric reflects the ideal of congruence between civil and religious law and that government should promote religious morality. It conflicts with the principle that moral disapproval alone is not a constitutionally legitimate basis for a discriminatory law. ${ }^{22}$ Thus, when the U.S. Supreme Court struck down section 3 of DOMA - which defined "marriage" for purposes of federal law as only the union of one man and one woman-as an unconstitutional "deprivation of the liberty of the person protected by the Fifth Amendment of the Constitution," it cited the House report's language as evidence that DOMA's purpose and effect was "interference with the equal dignity of same-sex marriages." ${ }^{23}$

\section{HOW U.S. FAMILY-LAW COURTS ACCOMMODATE}

\section{RELIGIOUS FAMILY LAW WITHIN THE CONTOURS OF CONSTITUTIONAL LAW AND PUBLIC POLICY}

Family law in the United States is already, to a degree, pluralist, but constitutional law and the values and public policies instantiated in family law shape the degree 
of legal pluralism. ${ }^{24} \mathrm{~A}$ useful organizing device is to distinguish two categories of family-law cases. In the first are cases in' which civil courts are asked to uphold or enforce terms of a religious marriage contract, divorce agreement, or arbitration agreements about marriage or divorce. Those cases generally reflect forms of private ordering that allow couples to alter or opt out of default rules that would otherwise apply to their marriage or divorce. Contemporary family law favors such private ordering. ${ }^{25}$ Moreover, the desire to abide by religious norms extends beyond family law: People and even businesses may agree to resolve their disputes through religious arbitration. ${ }^{26}$ When such private ordering occurs in the context of religious marriage and divorce, courts apply principles of contract law and make clear that, to avoid running afoul of the Establishment Clause, they can only uphold such agreements if they can apply "neutral principles."

The second category of cases involves the doctrine of comity; that is, whether a court will recognize - or refuse to recognize-a foreign marriage, divorce, or court order, which may also be based on religious family law. Given that individuals often cross national borders, marrying in one nation and divorcing in another, or engage in forum shopping to obtain more favorable terms in a religious or foreign forum, these cases may be complex.

A significant issue this body of law raises, as I elaborate elsewhere, is "how civil family law's concerns for procedural and substantive fairness shape the accommodation now afforded to religious law." For example, "religious family law often has gender asymmetries in the rights and duties of husbands and wives (including the power to initiate a divorce) and of fathers and mothers," and "rules concerning the economic consequences of marriage and divorce" in certain religious traditions "differ from the economic partnerships model of civil family law. ${ }^{27}$ Given the trend in family law toward private ordering, should a Muslim woman's agreement to forego economic sharing of property upon divorce because it is "un-Islamic," for instance, warrant closer scrutiny for voluntariness and fairness than a non-Muslim woman's agreement to do so because her more affluent spouse insists upon it as a precondition for marriage? ? $^{28}$

\section{RELIGIOUS MARRIAGE CONTRACTS, ARBITRATION} AGREEMENTS, AND DIVORCE AGREEMENTS

Courts sometimes enforce terms of marriage contracts entered into pursuant to Jewish or Islamic marriages. They do so mindful of First Amendment prohibitions on the establishment of religion, precluding courts from getting entangled with 
religious disputes. A leading case is Avitzur $v$. Avitzur, in which, following U.S. Supreme Court precedent, New York's Court of Appeals concluded it could use "neutral principles of contract law" - without resorting to religious doctrineto enforce a contractual obligation in a Jewish couple's marriage contract (the ketubab) that they would appear before the beth din, a Jewish religious tribunal, to allow it to "advise and counsel" them concerning their marriage. ${ }^{29}$ An aim of such arbitration clauses is to help the wife secure from her husband a get, a formal document of divorce, so that she is free to remarry and not be an agunah, a woman chained to her marriage..$^{\circ}$

In Odatalla $\nu$. Odatalla, ${ }^{31}$ a New Jersey court similarly relied on the "neutral principles" approach to reject a husband's argument that enforcing a mabr agree: ment, entered into during an Islamic marriage ceremony, to pay his wife $\$ 10,000$ in postponed dowry would "violate the separation of church and state." Using principles of contract law, the court held that the agreement was not too vague to be enforced, finding persuasive the wife's testimony about when payment could be demanded.

Courts have also upheld agreements by parties who are divorcing civilly to religious arbitration of the terms of their divorce. In Jabri v. Qaddura, for example, a divorcing Texas couple signed an "Arbitration Agreement" to submit all claims and disputes to binding arbitration "by the Texas Islamic Court." ${ }^{32}$ When they disagreed over the scope of the agreement, the trial court ruled the agreement was not valid or binding and refused to compel arbitration. The appellate court reversed, noting that "arbitration is strongly favored under federal and state law," and "every reasonable presumption must be decided in favor of arbitration. ${ }^{33}$

\section{EXAMPLES OF COURTS DECLINING TO ENFORCE}

\section{MARRIAGE CONTRACT TERMS}

Some state courts are less accommodating, concluding that the First Amendment bars them from enforcing terms of religious marriage contracts because they are "rooted in a religious practice," and therefore the obligation is "not a legal contract." ${ }_{34}$ Others conclude that payments to a wife that are contingent upon divorce violate public policy and punish the husband.

Some courts view religious marriage agreements as generally enforceable, but decline to enforce in particular cases because of a failure to satisfy basic rules of contract. Thus, in In re Marriage of Obaidi and Oayoum, a Washington appellate court reversed the trial court's enforcement of a term in the nikah, an Islamic 
marriage contract, requiring the husband to pay the wife $\$ 20,000$, the deferred portion of the mabr. ${ }^{35}$ The husband (raised in the United States and a U.S. citizen) and the wife (from Canada) were "children of Afghan immigrants": He signed a mabr agreement as part of the nikab ceremony. Subsequently, the couple had an "Islamic marriage ceremony," and then "solemnized their marriage civilly." ${ }^{6}$

On appeal, the appellare court cired Odatalla as a "helpful framework," indicating there was no First Amendment problem. By contrast to Odatalla, however, it concluded the mahr agreement was "invalid" under Washington's rules about the formation and validity of contracts because there was "no meeting of the minds on the essential terms of the agreement," such as "why or when the $\$ 20,000$ would be paid."37 Also, the husband learned of the mabr fifteen minutes before he signed it and had no opportunity to consult with legal counsel. His uncle conducted the negotiations in Farsi, a language unknown to the husband, and advised him after he signed the agreement. The reviewing court noted the trial court's.conclusion that "the agreement was influenced by duress," due to "a lot of pressure from both families. ${ }^{n}{ }^{38}$ On the one hand, this ruling is consistent with case law holding premarital and marital agreements unenforceable when circumstances indicate consent was not informed or voluntary (such as being presented with an agreement shortly before the wedding guests arrive). On the other hand, "in this cultural context, ... different expectations probably apply," as the husband, in adopting "a wedding format customary in his (Afghani) culture," would have "anticipated that the nikab included a mabr." ${ }^{39}$

\section{CASES INVOLVING COMITY}

A second category of cases involve whether, applying the doctrine of comity, a court will recognize foreign marriage contracts or divorce judgments (which may be based on religious law). One instructive example is Aleem $v$. Aleem, where a Maryland appellate court upheld a lower court's ruling that it need not give comity to a Pakistani talaq divorce (where the husband pronounced three times that he was divorcing his wife) and was not barred from ordering that the wife receive equitable distribution of her husband's pension. $4^{\circ}$ Maryland's highest court subsequently affirmed, stating that talaq divorce, where "only the male, i.e., husband, has an independent right to utilize talaq and the wife may utilize it only with the husband's permission, is contrary to Maryland's constitutional provisions and ... to the public policy of Maryland." 4

Aleem also illustrates judicial concern about strategic forum shopping that defeats the protective purposes of a state's family law. When the wife initiated 
a civil divorce, the couple had never lived together in Pakistan, but had lived in Maryland more than twenty years and reared two children, both U.S. citizens. The husband countered by obtaining a talaq divorce at the Pakistani Embassy in Washington, D.C. He then argued that their marriage contract.entered into in Pakistan and providing the wife a deferred dowry of $\$ 2,500$ should resolve any property issués. ${ }^{42}$ The court disagreed. Pakistani law's "default" rule, that a wife had no rights to property titled in her husband's name, directly conflicted with Maryland's "default" rule, that a wife had a right to division of equitable distribution of marital property (including her husband's pension). ${ }^{43}$ A critical factor in the Maryland court's conclusion that it could "effect an equitable distribution of marital property" was that there was a sufficient "nexus," or connection, between the couple's marriage and Maryland. ${ }^{44}$

In her informative study, Islamic Divorce in North America, Julie Macfarlane found similar attempts at forum shopping, in which a husband challenged civil divorce proceedings initiated by a wife, arguing "that the couple was already divorced by talaq in an overseas country," and that comity "absolves him from further financial responsibilities toward his ex-spouse." ${ }^{\text {45 }}$

\section{"SEVERANCE" OR WHOLESALE REJECTION OF “FOREIGN" RELIGIOUS LAW?}

Two recent cases demonstrate the contrast between what Malik calls (in this volume) a "severance," or issue-by-issue, approach to legal recognition of foreign (religious) law and a wholesale rejection of such law as incompatible with public policy, a stance fortified by state bans on judges applying foreign law.

In S.B. v. W.A. ${ }^{46}$ a wife asked a New York court to recognize and enter a divorce judgment entered in Abu Dhabi, in the United Arab Emirates (UAE). Notable is the court's careful examination of UAE law and its willingness to enforce the judgment, despite conflicts between UAE and New York law in areas not germane to that judgment. The couple married civilly in New York, as well as "in a religious ceremony under Islamic law," as part of which they signed a mabr agreement, ${ }^{47}$. When the wife, a U.S. citizen, sought divorce, they had relocated to Abu Dhabi for the husband's employment. Precipitating the divorce was the prosecution and conviction of the husband, "under Islamic Law" and the UAE's criminal law, for "violently commit[ing] outrage upon [the plaintiff/wife]," causing serious injuries. In the criminal trial, the court concluded that the facts supported the wife's account of her injuries and that the husband "crossed the legal limits to discipline 
his wife." On appeal, he unsuccessfully argued his conduct was within "a man's legal right upon his wife to discipline her," under the UAE penal code.: ${ }^{+8}$

The wife obtained a judgment of divorce on the basis of the husband's assault conviction and an order that he pay her deferred dowry, under the mabr, of \$250,000.49 Notably, the parties could have requested the Abu Dhabi court apply New York law to their divorce proceeding, but did nor.

The ex-husband returned to the United States to avoid enforcement of the divorce judgment, triggering the ex-wife's suit in New York for enforcement..$^{5 \circ}$ The New York court applied the "general principle" that "a divorce decree obtained in a foreign jurisdiction by residents of this State, in accordance with the laws thereof, is entitled to recognition under the principle of comity unless the decree offends the public policy of the State of New York." The grounds on which the wife obtained divorce in the UAE - "harm and damage" - were not "repugnant" to New York's public policy, but were similar to "cruel and inhuman treatment" under New York's family law."st The ex-husband argued that it violated New York's public policy that the Abu Dhabi court "entered a divorce judgment based upon the religious marriage and declined to recognize and litigate the civil marriage," but the court countered that the divorce was litigated in a "civilian state court, not a Sharia religious court."

Similarly unsuccessful was the husband's policy argument that "the laws of the UAE are based upon Sharia law." In notable contrast to the fears of "sharia law" shown by some courts and state legislatures (as I discuss later), the New York court reasoned that, while "parts of Sharia Law governing personal status would indeed violate our domestic policy, such as laws allowing husbands to practice polygyny and use of physical force to discipline their wives," "none of the principles used by the Abu Dhabi courts in the parties' divorce action" to "determine the financial issues" between them violated.New York's public policy. ing the foreign judgment that the defendant pay the wife "a distributive award" of \$250,000 based on the mabr agreement, the court invoked Avitzur to conclude that the agreement, entered into after the civil marriage ceremony (in New York), was a "post marital" or "antenuptial" contract obligation, enforceable "according to neutral principles of law" provided it did not violate state law or public policy.33 Fundamental principles of comity, the court concluded, supported enforcing the judgment: It was "rendered under a system of justice compatible with due process of law," and there was no evidence it was "procured through fraud" or that enforcing it "would be repugnant to the public policy of this state or of notions of fairness." ${ }^{34}$ 
By contrast to the fine-grained approach of the New York court in S.B.v.W.A., the court in a recent Kansas case, Soleimani v. Soleimani,"s viewed a mabr agreement entered into during an Iranian marriage ceremony between a U.S. citizen (the groom) and an Iranian citizen (the bride) as inextricably tainted by Islam's evidently unequal treatment of women in marriage and divorce. Enforcing it would, thus, entail "fashioning a remedy under a contract that clearly emanates from a legal code that may be antithetical to Kansas law." The court found several problems with the mabr agreement as a matter of Kansas's contract law, but made clear that its more fundamental objection was that such agreements "stem from jurisdictions that do not separate church and state and may, in fact, embed discrimination through religious doctrine. ${ }^{56}$ In support, the court invoked Kansas's newly enacted ban on judicial enforcement of "foreign" law. Finally, the court accepted the husband's argument that enforcing the mabr would violate public policy by displacing Kansas's family law with respect to economic distribution of property at divorce.

Solemaini reflects an unwarranted fear of "too much pluralism" in family law. In dramatic terms, the court perceived a clash in values between two legal regimes: "the protection of Kansas law ... requires an equitable division of property in a secular system that is not controlled by the dictates or religious authorities or even a society dominated by men who place values on women in medieval terms." ${ }^{37} \mathrm{~A}$ striking aspect of the opinion is that the court shows some basic understanding of Islamic family law, but the gender asymmetries of that law function as reasons not to enforce the mabr agreement. The court observed that because Islamic law, like "traditional Jewish law," allows men "to unilaterally declare a divorce," the mabr is "a means of tempering the inequities of traditional religious law" and may be "culturally justified." 88 However, the fact that "wives have no right to pronounce the talaq" violates the Equal Protection Clause requirement that the law not treat persons differently based on "arbitrary or invidious" distinctions. The case before it, however, did not involve a talaq divorce; nonetheless, it noted that Michigan state courts declined to give comity to foreign talaq divorces because those legal systems deny equal protection under Michigan's laws.99

The Kansas court expressed concern over abdicating its "overall constitutional role to protect ... fundamental rights," citing the Kansas legislature's then-new law barring judicial use of foreign law, which provided:

A contract or contractual provision, if capable of segregation, which provides for the choice of foreign law, legal code, or system to govern some or all of the disputes between the parties adjudicated by a court of law or by an arbitration 
panel arising from the coneract mutually agreed upon shall violate the public policy of this stare and be void and unenforceable if the foreign law, legal code, or system chosen includes or incorporates any substantive or procedural law, as applied to the dispute at issue, that would not grant the parties the same fundamental liberties, rights, and privileges granted inder the United States and Kansas constitutions, including, but not limited to, equal protection, due process, free exercise of religion, freedom of speech or press, and any right of privacy or marriage. ${ }^{60}$

The court cited Kansas's ban to fortify its concern about upholding religious law that arbitrarily discriminates against wives, ${ }^{61}$ but refused to enforce a wife's right to the deferred portion of the mahr ( $\$ 677,0000$ at divorce) because it would impose an exorbitant economic penalty on her busband. The court accepted the husband's argument that the mabr offended public policy because "it would interfere with the Court's ability to make a just and equitable division [of property] under Kansas law," without regard to fault. ${ }^{62}$ The court also cited to California cases ruling that terms in Jewish and Islamic religious marriage contracts that provided the wife a substantial payment of money or half of the husband's property in the event of divorce offended public policy because they encouraged divorce. ${ }^{63}$

Once again, the Kansas court shows some understanding of Islamic family law, citing scholarly sources, but refuses to engage in a careful, contextual evaluation of whether enforcing the mabr would violate public policy. Thus, it observes that, "In Islamic tradition, each spouse retains their own.assets as separate property during the marriage, and so marital or community property is foreign to Islam." Mahr negotiations, thus, by contrast to premarital agreements, "do not represent an attempt to bargain around default divorce laws." It then casts doubt on whether the "neutral principles of law" approach is realistic, given the "Islamic shadow behind which husband and wife" negotiate the mabr; frequently, they did so in home countries without U.S. family law's default rules and did not "anticipate litigation in American courts and confronting state equitable division or community property laws. ${ }^{64}$ However accurate this description may be of the reasonable expectations of Muslims unfamiliar with U.S. law, it hardly describes Mr. Soleimani. He left Iran for the United States in 1977, became a-naturalized U.S. citizen, and was quite familiar with Kansas's law of equitable distribution as, when he divorced his first wife of 30 years in a Kansas civil proceeding, they both received marital property! Moreover, subsequent to the Iranian marriage ceremony, he married his second wife civilly and resided with her in Kansas. ${ }^{65}$ As Macfarlane observes: "In practice, many modern Muslim couples [in North America] have an expectation of sharing 
assets and resources both during their marriage and if they come to resolve the financial consequences of divorce," whether such agreement is "formally incorporated in their nikah, or more commonly simply an understanding between them." ${ }^{966}$ Seen in this context, then, the Aleem case, on which the Kansas court relies, was an unsuccessful end-run around such economic sharing: The husband, a long-time U.S. resident, contended the mabr payment of $\$ 2,500$ should exhaust his wife's economic rights at divorce, while under Maryland law of equitable distribution, the wife was entitled to at least half of the $\$ 2$ million in marital property. ${ }^{67}$

One can conclude both that Aleem was correct and that Soleimani was incorrect. Rather than viewing the $m a b r$ agreement either as negotiated in ignorance of Kansas law or as an attempe to displace Kansas's family law, the court might better have considered it as one factor in determining what distribution of marital property would be equitable in the parties' short marriage. If paid, it would also be an asset in the ex-wife's column that would likely eliminate her need for any spousal support and would be a debt in the husband's column that could affect his ability to pay any support..$^{68}$

\section{"ANTI-SHARIA LAWS" OR BANS ON "FOREIGN LAW": A REJECTION OF FAMILY-LAW PLURALISM}

The Kansas law to which the Soleimani court referred is emblematic of a wave of laws proposed or enacted in state legislatures "to ban the use of foreign or international law in legal disputes", spurred by "fears that Islamic laws and customs-commonly referred to as 'Sharia'-are taking over American courts." ${ }^{\text {"69 }}$ These bills generally use as a template model legislation drafted by a small group of "anti-Muslim activists" who warn that Islamic extremists seek to supplant U.S. constitutional and state law -. particularly, family law-with sharia, with dire consequences, particularly for women..$^{\circ}$ These laws "grossly mischaracterize-both the meaning and practice of Sharia," including the "diversity of interpretation of Islam." ${ }^{\text {"1 }}$ In effect, they reject the legal pluralism present in U.S. family law while failing to understand that the U.S. Constitution and family law already limit the application by judges in the U.S. legal system of religious and foreign law.

The first generation of such laws specifically targeted "sharia law." Thus, Oklahoma State Representative Rex Duncan characterized his proposed constitutional amendment (the Save Our State amendment) as a "war for the survival of our 
country" and over "what religion should undergird civil law." ${ }^{2}$ The amendment, he argued, was a "simple effort to ensure that our courts are not used to undermine" America's founding "Judeo-Christian principles." ${ }^{\text {"73 }}$ Contemporaneous reports contended that sharia rejected many basic American values, including equal treatment under the law (of men and women, and Muslims and non-Muslims) and warned of the establishment of a "global Islamic state" with objectives "incompatible with the U.S. Constitution" and "the civil rights" it guarantees. ${ }^{74}$

On November 2, 2010, 70 percent of Oklahoma citizens approved the Save Our State amendment, which provided: "The courts shall not look to the legal precepts of other nations and cultures. Specifically, the courts shall not consider international law or Sharia Law."7s After a challenge brought by Mr. Muneer Awad, an American citizen residing in Oklahoma and executive director of the Oklahoma chapter of the Council of American-Islamic Relations (CAIR), a federal court enjoined the amendment. ${ }^{7} \mathrm{Mr}$. Awad argued that he had suffered multiple injuries. The amendment officially condemned and disfavored his religion, in violation of the Establishment Clause, and made it impossible for his last will and testament, which was based in sharia, to be executed by the court.7 The Tenth Circuit affirmed, noting that the amendment singled out "only one form of religious lawSharia law," and "discriminates among religions," triggering review under the strict scrutiny test. ${ }^{8}$ Oklahoma failed this test. The Tenth Circuit concluded that Oklahoma's interest in "determining what law is applied in Oklahoma courts," while "valid," was not "compelling" because the defendants did not "identify any actual problem the challenged amendment seeks to solve" and "did not know of even a single instance where an Oklahoma court had applied Sharia law or used the legal precepts of other nations or cultures." ${ }^{99}$ The court observed that the ban went far beyond "preventing courts from 'applying' Sharia law" to forbidding them from "considering' those laws."

In light of the fate of Oklahoma's law, the next generation of foreign-law bans (such as in Kansas) omitted specific reference to a specific culture or religion. ${ }^{{ }^{8}}$ Indeed, many bans "are so broadly phrased as to cast doubt on a whole host of personal and business arrangements," which is a reason that many groups, including faith communities, have "mobilized against them." ${ }^{\text {" }}$ Commentators correctly observe that these laws are usually unnecessary "smoke and mirrors:" When courts are asked to enforce agreements that use Jewish and Muslim laws-as they routinely are-if there is a conflict between U.S. constitutional and family law and religious law, U.S. law prevails. ${ }^{83}$ 


\section{“MY RELIGION MADE ME DO IT"}

One spur for bans on sharia was a New Jersey court judge's highly publicized failure, in S.D. v. M.J.R., to find that a husband had raped his wife because of his asserted religious belief that his conduct was permitted. This case illustrates a third category of case in which courts confront religious family law: the assertion of a religious defense to important public laws against domestic violence and sexual assault. The New Jersey judge ruled against a Muslim woman, who sought a permanent restraining order against her spouse after he raped and abused her repeatedly, because - as CNN reported it - "her husband was abiding by his Muslim beliefs regarding spousal ducies." ${ }^{4}$ The judge was reversed and rebuked on appeal, but his ruling "sparked a nationwide firestorm," as proponents of anti-sharia laws cited it as evidẹnce of "creeping" sharia encroaching on the rule of law. ${ }^{85}$

S.D. v. M.J.R. offers a disturbing example of the "my culture [or religion] made me do it" defense: when people appeal to "culture" or "religion" to justify sexist, violent practices, and, what's worse, judges or legislators sometimes credence these claims. ${ }^{86}$ Both the wife/plaintiff, S.D., and the defendant/husband, M.J.R., were Moroccan citizens and Muslims, living in New Jersey. They married in Morocco in an arranged marriage when. she was $I 7$ and "did not know each other prior to the marriage." ${ }^{7}$ The wife asserted repeated abusive treatment by her husband-including rape-during a very short marriage. She alleged that he rationalized his conduct, telling her: "this is according to our religion. You are my wife, I c [an] do anything to you. The woman, she should submit and do anything I ask her to do." 88

Eventually, the husband verbally divorced his wife, who obtained a temporary restraining order against him. The trial court found that she proved by a preponderance of the evidence that the defendant engaged in "harassment" (based on "clear proof" of nonconsensual sex) and "assault," but ruled that even though the defendant "had engaged in sexual relations with plaintiff against her expressed" wishes" on at least two occasions, he lacked a "criminal desire to or intent to sexually assault" because he believed his conduct was not prohibited by his religion. The trial court, for example, cited the imam's testimony that under Islamic law, "a wife must comply with her husband's sexual demands." However, while the imam "did not definitely answer whether, under Islamic. law, a husband must stop his advances if his wife said 'no," he "acknowledged that New Jersey law considered coerced sex between married people to be rape." ${ }^{\text {g }}$ 
On appeal, the reviewing court reversed and sharply reprimanded the trial court. This appellate opinion better reflects how U.S. courts should-and usually do-resolve situations in which, as the trial court perceived it, "religious custom clashed with the law," particularly laws with a protective function. $9^{\circ}$ In a conflict between criminal law and religious precepts, the appellate court made clear, the state's criminal statutes must prevail. In support, it cited Reynolds v. United States, where the U.S. Supreme Court upheld a criminal conviction for bigamy despite. a Mormon's asserted religious belief that it was a duty to practice polygamy. ${ }^{91}$ The court also cited Employment Division, Department of Human Resources of Oregon v. Smith, ${ }^{22}$ in which the Supreme Court ruled that valid, neutral laws of general application may be applied to religious exercise, even without a compelling state interest. Thus, because New Jersey's sexual assault laws were "neutral laws of general application" and the defendant knowingly engaged in conduct violating them, the trial court erred in refusing to recognize those violations as a basis for a determination "that defendant had committed acts of domestic violence." Legislative findings asserting the seriousness of domestic violence and the responsibility of courts to protect domestic violence survivors offered "an additional basis" for rejecting the lower court's view.93

The appellate court also ruled that the trial court erred in not issuing the wife a final restraining order against the husband, on the rationale that the parties had undergone a "bad patch" in their marriage, but her injuries were "not severe" and, after divorce, a restraining order was "not necessary to prevent another act of domestic violence." However, because the plaintiff was pregnant, the judge conceded the parties would need to be in some contact.94 The appellate court stated that under New Jersey's domestic violence statute, courts have an obligation to "protect victims of violence that occurs in a family." It expressed concern that the trial judge's "view of the facts ... may have been colored by his perception that, although defendant's sexual acts violated applicable criminal statues, they were culturally acceptable and thus not actionable-a view we have soundly rejected."9s

The "strong reprimand" delivered by the New Jersey appellate court and its message that public policy trumps the appeal to (foreign) religious belief should "prove that the American justice system works" and that foreign-law bans are unnecessary.96 As one attorney commented on the case: "foreign law or religious law in America is considered within American constitutional strictures." He added that while a minority of Muslims mistakenly hold a contrary belief, "the appellate ruling is consistent with Islamic law, which prohibits spousal abuse." 97 


\section{CONCLUSION}

In this chapter, I have argued that family law in the United States includes a mild form of legal pluralism, which accommodates religion by allowing people room to order their family lives in keeping with their religious beliefs. In an era when families increasingly cross national borders, family court judges give legal recognition to foreign marriage contracts and divorce judgments when principles of comity support doing so. This legal pluralism is mild rather than robust because it is appropriately constrained by the requirements of U.S. constitutional law and family law. Through illustrative cases, I highlighted how courts capably work within this framework, while noting that some courts reject such pluralism, particularly in light of the recent spate of "anti-Sharia laws" or foreign-law bans being considered or enacted across the United States. These bans, I have argued, reflect a misguided fear of a takeover of U.S. courts by religious law in conflict with basic values such as the equality of women in the realm of marriage and divorce. Seen most charitably, such laws emphatically instruct courts to "follow the constitution" and make sure it trumps in such a conflict. ${ }^{98}$ I have argued, however, that courts already understand that directive as they shape the mild legal pluralism of U.S. family law:

\section{NOTES}

I. I thank Mirjam Künkler and Ann Estin for insightful commentary on earlier drafts of this chapter. Thanks to former Boston University Law students Christina BorysthenTcakz, Alexandria Guitierrez, and Kate Lebeaux and to Stefanie Weigmann, assistant director for Research, Faculty Services, and Education Technology, Pappas Law Library, for valuable research assistance. Thanks to former Boston University Law student Gillian Stoddard Leatherberry for editorial help.

2. In her commentary on this chapter, Mirjam Künkler used these terms.

3. Maleiha Malik, "Religion and Minority Legal Orders," this volume.

4. See Cully Stimson, "The Real Impact of Sharia Law in America," The Foundry, September 2, 2010. Available at http://blog.heritage.org/2010/09/02/the-real-impact-of -sharia-law-in-america/.

5. For this distinction, see Ann Laquer Estin, "Unofficial Family Law," in Marriage and Divorce in a Multicultural Context: Multi-tiered Marriage and the Boundaries of Civil Law and Religion, ed. Joel A. Nichols (Cambridge: Cambridge University Press, 2012), 92-I19.

6. Ibid., 95 .

7. Abner Greene, Against Obligation: The Multiple Sources of Authority in a Liberal Democracy (Cambridge, MA: Harvard University Press, 2012), 2. 
8. Sally Engle Merry, "Legal Pluralism," Law and Society Review 22 (1988): 869, 879.

9. Linda C. McClain, "Marriage Pluralism in the United States: On Civil and Religious Jurisdiction and the Demands of Equal Citizenship," in Marriage and Divorce in a Multicultural Context: Multi-tiered Marriage and the Boundaries of Civil Law and Religion, ed. Joel A. Nichols (Cambridge: Cambridge University Press, 2012), 309-340; 339.

ro. Ann Lacquer Estin, "Foreign and Religious Family Law: Comity, Contract, and the Constitution," Pepperdine Law Review 4I (2014):1029, 1029-1030; Ann Estin, "Embracing Tradition: Pluralism in American Family Law," Maryland Law Review 63 (2004): 540, 541; see also McClain, "Marriage Pluralism," 339.

II. Goodridge v. Department of Public Health, 798 N.E. 2d 94I (Mass. 2003).

12. See Persad v. Balram, 724 N.Y.S.2d 560 (Sup. Ct. Queens County 2001) (declaring a marriage lawful despite the failure to obtain a marriage license and although the religious officiant had not registered with the City of New York, as the couple "participated in a Hindu marriage or 'prayer' ceremony" presided over by an "ordained Hindu priest," made vows and exchanged rings, had a large reception, with wedding cake and gifts, and sent thank you notes).

13. On this point, see Lynn Welchman, ed., Women's Rights and Islamic Family Law: Perspectives on Reform (London: Zeb Books, 2004), 188.

14. Estin, "Unofficial Family Law," 99.

15. Homer Clark, The Law of Domestic Relations in the United States, and ed. (St. Paul, MN: West Group, 1988), 3 I.

16. Ibid., 3I.

17. Goodridge, 954.

18. Ibid., 948-49.

19. New York's Marriage Equality Act is illustrative. For discussion, see James E. Fleming and Linda C. McClain, Ordered Liberty: Rights, Responsibilities, and Virtues (Cambridge, MA: Harvard University Press, 2013), 199-205. More recent controversies concern whether such exemptions should include owners of for-profit businesses who object, on religious grounds, to same-sex marriage.

20. H.R. Rep. No. 104-664, at 15-16.

21. For claboration on "congruence," sec McClain, "Marriage Pluralism," 312-17.

22. See Lawrence v. Texas, 539 U.S.558 (2003) (O'Connor, J., concurring).

23. United States $\nu$. Windsor, 133 S. Ct. 2675 (2013).

24. For elaboration on this case law, see McClain, "Marriage Pluralism," 320-29; Estin, "Embracing Tradition," 540-604.

25. Douglas Abrams, Naomi R. Cahn, Catherine J. Ross, David D. Meyer and Linda C. McClain, Contemporary Family Law, 4th ed. (St. Paul, MN: West Group, forthcoming 20I5) (Chapter 16). Private ordering is more restricted with respect to child support and, sometimes, child custody.

26. Michael A. Helfand, "Religious Arbitration and the New Multiculturalism: Nègotiating Conflicting Legal Orders," NYU Law Review 86 (2011): 1231-305; Mark Oppenheimer, "Before Turning to a Judge, an Argument for Turning First to Jesus," New York Times, March 1, 2014, AI7. 
27. McClain, "Marriage Pluralism."

28. For a helpful discussion, see Julie Macfarlane, Islamic Divorce in North America (New York: Oxford University Press, 2012), 222-39.

29. Avitzur v. Avitzur, 446 N.E.2d 136 (N.Y. 1983) (citing Jones v. Wolf, 443 U.S. 595,602 [1979]).

30. Since Avitzur, the New York legislature has added provisions to New York's domestic relations law to address the agunah problem, triggering intense debate "within the Jewish tradition and within the secular legal community." Michael J. Broyde, "New York's Regulation of Jewish Marriage," in Marriage and Divorce in a Multicultural Context: Multi-tiered Marriage and the Boundaries of Civil Law and Religion, ed. Joel A. Nichols (Cambridge: Cambridge University Press, 2012), 138, 154.

31. Odatalla v. Odatalla, 810 A.2d 93 (2002) (also citing Jones v. Wolf).

32. Jabri v. Qaddura, 108 S.W.3d 404 (Tex. Ct. App. 2nd Dist. 2003).

33. Ibid., 4 IO.

34. Macfarlane, Islamic Divorce, 225 (quoting a 2007 case from Ohio in which the court refused to enforce a mabr agreement).

35. In re Marriage of Obaidi and Qayoum, I54 Wash. App. 609, 611 (Wash. 2012).

36. Ibid., GII-I3.

37. Ibid., 615, 616. The appellate court observed that the trial court departed from neutral principles in "considering Islamic law" as to the wife's fault in determining whether the wife should be paid the mahr.

38. Ibid., 1617.

39. Macfarlane, Islamic Divorce, 221.

40. Aleem v. Aleem, 931 A.2d 1123 (Md. Spec. App. 2007), aff'd, 947 A.2d 489 (Md. 2008).

4I. Aleem, 947 A.2d at 500-50I.

42. Aleem, $93 \mathrm{I}$ A.2d at $\mathrm{Ir} 27$.

43. Ibid., 1134 .

44. Ibid., 113 I.

45. Macfarlane, Islamic Divorce, I66. Not all wives fared as well as the wife in Aleem.

46. 959 N.Y.S.2d 802 (N.Y. Sup. Ct. 2012).

47. Ibid., $8 \circ 8$.

48. Ibid., 8 Ir.

49. Ibid., 812 .

5o. I omit many of the procedural twists and turns in this case because of space constraints.

5I. Ibid.

52. Ibid., 818-19.

53. Ibid., 819-21.

54. Ibid., 822.

55. Solemaini v. Soleimani, No. $\mathrm{ICV}_{4} 668,2012$ WL 37729939 (Kan. Dist. Ct. Aug. 28, 2012).

56. Ibid., 7-8. The court stated that the agreement was in Farsi, "no competent English translation" was introduced or admitted, and the wife "did not prove a contract existed that the Court could interpret, while adhering to the rules of evidence" (8). Further, the 
mabr was "ambiguous" as to when payment may be demanded, and resolving this ambiguity would require "evidence" of Iranian and Islamic law (8).

57. Ibid., 18.

58. Ibid., 14-15.

59. Ibid. (citing, e.g., Tarikonda v. Pinjari, 2009 WL $93007^{*} 3$ (Mich. Ct. App. April 7, 2009).

60. Soleimani, 15-16 (citation omitted). The portion quoted in text is section 4 of what became Kansas Starutes Annotared 60-5101 (2012).

61. Soleimani, 15-16.

62. Ibid., II.

63. Ibid., 13-14 (discussing In re Marriage of Noghrey, 215 Cal. Rptr. 153 [Cal. App. 6th Dist., 1985] [refusing to enforce term of ketubab] and Dajani v. Dajani, 25I Cal. Rptr. 871 [Cal. App. 4th Dist. 1988] [refusing to enforce "foreign dowry agreement" in proxy marriage contract]). I critically evaluate these cases in McClain, "Marriage Pluralism," 325-26.

64. Soleimani, 18 (citations omitted). Robert H. Mnookin and Lewis Kornhnauser, "Bargaining in the Shadow of the Law," Yale Law Journal 88 (1979): 950.

65. Soleimani, 2.

66. Mafarlane, Islamic Divorce, 191-92.

67. Soleimani, 18 (citing Aleem, 493 n. 5).

68. The husband argued he could not pay the mabr.

69. Faiza Patel, Matthew Duss, and Amos Toh, Foreign Law Bans: Legal Uncertainties and Practical Problems (Washington, DC: Center for American Progress and Brennan Center for Justice, May 2013).

70. Ibid., s (describing efforts of David Yerushalmi); see also Paul Berger, "Jewish Divorce Caught in Sharia Law Fight," Forward, March 9, 2012. Available at http://forward.com /articles/152534/jewish-divorce-caught-in-sharia-law-fight/?p=all; Stimson, "The Real Impact of Sharia Law"; Yaser Ali, "Shariah and Citizenship-How Islamophobia Is Creating a Second-Class Cirizenry in America," California Law Review roo (2012): 1027.

71. Patel et al., Foreign Law Bans, s; Justin Elliott, "What Sharia Law Actually Means," Salon, February 26, 201r. Available at www.salon.com/2011/02/26/sharia_th_real_story/.

72. Lee Tankle, "The Only Thing We Have to Fear Is Fear Itself: Islamophobia and the Recently Proposed Unconstitutional and Unnecessary Anti-Religion Laws," William and Mary Bill of Rights Journal 21 (2012): 273, 284.

73. Ibid.

74. Center for Security Policy, "Shariah-The Threat to America," 20ro. Available at www .centerforsecuritypolicyorg/2010/09/13/shariah-the-threat-to-america-2/.

75. Oklahoma Constitution, Art. VII, \$ I.

76. Awad v. Ziriax, 754 F. Supp. 1298 (W.D. Okla. 2010).

77. Ibid.

78. Awad v. Ziriax, 670 F.3d 1111, 1129, 1132-33 (10th Cir, 2012).

79. Ibid., 1130 (citing Awad, 754 F. Supp.2d at 1308).

8o. Ibid., 1130, 1131. 
81. See Patel et al., Foreign Law Bans, 1 and Table I (as of 2013, "lawmakers in 32 states have introduced and debated these types of bills," which have been enacted in Oklahoma, Kansas, Louisiana, Tennessee, and Arizona).

82. Ibid., I

83. Berger, "Jewish Divorce" (quoting Mark Stern); see also Barbara Bradley Hagerty, "Religious Laws Long Recognized by U.S. Courts," NPR, September 8, 2010. Available at www.npr.org/templates/story/story.php?storyId=1297310Is.

84. Bill Mears, "Federal Court Blocks Oklahoma Ban on Sharia," CNN, January 10, 2011. Available at www.cnn.com/2012/or.10/justice/oklahoma-sharia/index.html.

85. Ibid.; see also Hagerty, "Religious Laws Long Recognized."

86. Bonnie Honig, "My Culture Made Me Do.It," in Is Multiculturalism Bad for Women?, ed. Joshua Cohen and Susan Moller Okin, 35-40 (Princeton, NJ: Princeton University Press, 1999); see also Anne Phillips, Multiculturalism Without Culture (Princeton, NJ: Princeton University Press, 2007); Alison Dundes Renteln, The Cultural Defense (New York: Oxford University Press, 2004).

87. S.D. v. M.J.R., 2 A.3d $4 \mathrm{I} 2$ (N.J. Super. A.D. 2010).

88. Ibid., 415-16.

89. Ibid., 417-18.

90. Ibid., $420,422$.

91. Ibid., 422 (citing Reynolds v. United States, 98 U.S. 145 [1878]).

92. 494 U.S. 872 (1990).

93. S.D., 426 .

94. Ibid., 419 .

95. Ibid., 426-28.

96. Tankle, “The Only Thing We Have to Fear," 284.

97. Elliott, "What Sharia Law Actually Means" (quoting Abed Awad).

98. I owe this insight to Ann Estin.

\section{B I B L I O G R A P H Y}

Abrams, Douglas E., Naomi R. Cahn, Catherine J. Ross, David D. Meyer and Linda C. McClain. Contemporary Family Law (4th ed.). St. Paul, MN: West Group, 2015.

Ali, Yaser. "Shariah and Citizenship-How Islamophobia Is Creating a Second-Class Citizenry in America." California Law Review 100 (2012): 1027-68.

Broyde, Michael J. "New York's Regulation of Jewish Marriage." In Marriage and Divorce in a Multicultural Context: Multi-tiered Marriage and the Boundaries of Civil Law and Religion, edited by Joel A. Nichols, 138-163. New York: Cambridge University Press, 2012.

Clark, Homer. The Law of Domestic Relations in the United States (2nd ed.). St. Paul, MN: West Group, 1988.

Estin, Ann Laquer. "Embracing Tradition: Pluralism in Amerịcan Family.Law." Maryland Law Review 63 (2004): 540-604. 
Estin, Ann Laquer. "Foreign and Religious Family Law: Comity, Contract, and the Constitution." Pepperdine Law Review 41 (2014):1029-47.

Estin, Ann Laquer. "Unofficial Family Law." In Marriage and Divorce in a Multicultural Context: Multi-tiered Marriage and the Boundaries of Civil Law and Religion, edited by Joel A. Nichols, 92-119. New York: Cambridge University Press, 2012.

Fleming, James E., and Linda C. McClain. Ordered Liberty: Rights, Responsibilities, and Virtues. Cambridge, MA: Harvard University Press, 2013.

Greene, Abner. Against Obligation: The Multiple Sources of Authority in a Liberal Democracy. Cambridge, MA: Harvard University Press, 2012.

Hefland, Michael. "Religious Arbitration and the New Multiculturalism: Negotiating Conflicting Legal Orders." NYU Law Review 86 (2011): 1231-1305.

Honig, Bonnic. "My Culture Made Me Do It." In Is Multiculturalism Bad for Women?, edited by Joshua Cohen, 35-40. Princeton, NJ: Princeton University Press, 1999.

Macfarlane, Julie. Islamic Divorce in Nortb America. New York: Oxford University Press, 2010. McClain, Linda C. "Marriage Pluralism in the United States: On Civil and Religious Jurisdiction and the Demands of Equal Citizenship." In Marriage and Divorce in a Multicultural Context: Multi-tiered Marriage and the Boundaries of Civil Law and Religion, edited by Jocl A. Nichols, 309-340. New York: Cambridge Universiry Press, 2012.

Merry, Sally Engle. "Legal Pluralism." Law and Society Review 22 (1988): 869-96.

Mnookin, Robert H., and Lewis Kornhnauser. "Bargaining in the Shadow of the Law." Yale Law Journal 88 (1979): 950-97.

Patel, Faiza, Matthew Duss, and Amos Toh. Foreign Law Bans: Legal Uncertainties and Practical Problems. Washington, DC: Center for American Progress and Brennan Center for Justice, 2013.

Phillips, Anne. Multiculturalism Without Culture. Princeton, NJ: Princeton University Press, 2007.

Renteln, Alison Dundes. The Cultural Defense. New York: Oxford University Press, 2004.

Tankle, Lee. "The Only Thing We Have to Fear Is Fear Itself: Islamophobia and the Recently Proposed Unconstitutional and Unnecessary Anti-Religion Laws." William \& Mary Bill of Rights Journal 21 (2012): 273-302.

Welchman, Lynn, ed. Women's Rights and Islamic Family Law: Perspectives on Reform. London: Zeb Books, 2004. 